4. Orlova, A. P. (2016). Istoriya pedagogiki: etyudy o znamenitykh shkolakh (pervaya polovina $X X$ veka) [The history of pedagogy: studies of famous schools (first half of the twentieth century)]. Vitebsk. VGU imeni P. M. Masherova. 52 p. [in Russian].

5. Cherkasova, O. V. (2005). Gumanisticheskiye shkoly XX veka [Humanistic schools of the twentieth century]. Samara, 231 p. [in Russian].

6. Bettelheim, B. (1990). Themen meines Lebens, Essays über Psychoanalyse, Kindererziehung und das judische Schiksal [Topics of my life, essays on psychoanalysis, parenting and the fate of Jews]. Stuttgart. [in German].

7. Grossman, R. (1990). Solving the puzzle that was Bruno Bettelheim. Available at: https:// www.chicagotribune.com/news/ct-xpm-1990-11-119004030282-story.html [in English].

8. Krumenacker F.-J. (1998). Bruno Bettelheim: Grundpositionen seiner Theorie und Praxis [Bruno Bettelheim: basic principles of his theory and practice]. München, UTB. [in German].

Стаття надійшла до редакції 18.12.2019

УДК 378. 37.013:78

DOI:

Сергій Пішун, кандидат педагогічних наук, доиент кафедри педагогіки і психології початкової освіти Глухівського національного педагогічного університету імені Олександра Довженка

\title{
ІНТЕГРАЦІЯ МУЗИЧНО-ПЕДАГОГІЧНИХ КОМПОНЕНТІВ У ПРОФЕСІЙНІЙ ПІДГОТОВЦІ МАЙБУТНІХ УЧИТЕЛІВ МУЗИКИ В ПОЧАТКОВІЙ ШКОЛІ
}

У статті розглянуто окремі теоретичні передумови, щуо дозволяють проаналізувати процес розвитку професійної компетентності майбутніх учителів музики в умовах вищого закладу освіти, визначити пріоритети в прочесі професійної підготовки відповідно до характеру музично-педагогічної діяльності, до якої готуються майбутні вчителі музики, а саме: розглядається сутність процесу професійної підготовки вчителів музики, їі складові; аргументовано загальні та спеціальні вимоги до вчителів музики; аналізується зміст їх діяльості.

Ключові слова: компоненти; майбутній учитель; музично-педагогічна діяльність; освіта; особистість; початкова школа; професійна підготовка;

Puc. 1. Лim. 6.

Serhiy Pishun, Ph.D.(Pedagogy), Associate Professor of the Pedagogy and Psychology of Primery School Department, Hlukhiv Oleksandr Dovzhenko National Pedagogical University

\section{INTEGRATION OF MUSIC-PEDAGOGICAL COMPONENTS IN PROFESSIONAL TRAINING OF FUTURE MUSIC TEACHERS IN PRIMARY SCHOOL}

Modern status of professional training of music teachers allows confirming that there are certain reserves that favor to more successful development of special competence of future music teachers. This competence causes the effectiveness enhancing of his/her professional training process in higher educational establishment in general. The search for reserves is determined by the accents of its main structural components - pedagogical and musical. On the basis of its integration and complementarity lies the consideration of that activity which we are training future music teachers to.

Integrative approach in education which gives us the opportunity to do meaningful generalizations and integrate them further in musical and educational activity of future music teachers, shows positive results, enhances the qualitative level of classes in different subjects. The essence of integration as a process of convergence of knowledge, theory and practice, at the same time, doesn't deny the subject system of training and education of a specialist in a university. The task of comprehensive professional training of students - future music teachers should be, first and foremost, within the framework of one music cycle, and then - to be based on the knowledge and skills acquired by students while studying psychological and pedagogical disciplines. Integration, in turn, aims at deepening the interconnections between disciplines, fields of knowledge, scientific knowledge with practice, thus ensuring the integrity of the learning process. As a result, the principle of integration is, to our mind, the most important prerequisite for the whole process of professional training of a future music teacher.

Integrated learning activity emerges as a factor that enhances the students' educational and cognitive activity, forming a unity of meaningful, motivational and operational aspects of this activity. So integration is not 
just an innovation. It is a necessity for organizing a real pedagogical process that allows solving many problems related to cross-curricular issues, increasing the volume of information and many others.

Keywords: components; a future teacher; music-pedagogical activity; an education; personality; Elementary School; professional training.

П остановка проблеми. В останні десятиліття педагогічна теорія та практика знаходиться в активному пошуку методів, форм і засобів модернізації професійної підготовки вчителів мистецтва. Первинним, на наш погляд, $є$ визначення принципів та дидактичних умов, а методи і засоби, у свою чергу, обираються відповідно до них. Досить широка амплітуда професійної діяльності майбутніх учителів музики повинна визначати й відповідну підготовку, володіння різнобічними професійними (музично-педагогічними) знаннями та уміннями. Їх готовність до реалізації музичнопедагогічної діяльності може бути детермінована сукупністю всіх знань, умінь і навичок, від використання яких буде залежати вирішення завдань музично-естетичного виховання учнівпочатківців.

У нових історичних умовах у нестабільному світі, що стрімко змінюється, потрібна людина, яка не тільки знає, але найголовніше підготовлена до життедіяльності та освіти протягом усього життя. Що стосується музичної освіти, то питання, як за чотири роки бакалаврату підготувати педагога-музиканта, який володіє набором ключових для цієї професії компетенцій, викликає сумніви. У зв'язку з цим актуалізується пошук шляхів оптимізації освітнього процесу у вищому закладі освіти. 3 одного боку, за рахунок варіативної частини в навчальному плані з'явилося багато дисциплін, пропонованих вишем на вибір студента, що створює умови для формування його індивідуальної траєкторії навчання. 3 іншого боку, існуюча міжпредметна роз'єднаність у викладанні дисциплін може стати ще більш відчутною. У цих умовах зростає роль інтегрованого підходу до професійної підготовки педагога-музиканта [6].

Виокремлення будь-якого 3 предметів як одного з головних в підготовці вчителів музики (диригування, фортепіано або історикотеоретичних дисциплін) не зможе забезпечити вирішення завдань, що стоять перед масовим музичним вихованням, поки ці окремі ланки не стануть функціонувати як цілісна структура, а міжпредметні зв'язки й стосунки не стануть тим головним, що об'єднує всі ці предмети навчального плану й види діяльності студентів [1, 18]. Урок музики в школі ось та інтегративна платформа, навколо якої повинен будуватися художньо-педагогічний процес підготовки майбутніх учителів музики.
Аналіз останніх досліджень і публікацій. На необхідності забезпечення інтеграційних зв'язків у мистецькому навчанні наголошують Л. Масол, Н. Миропольська, О. Отич, О. Рудницька, О. Щолокова, Б. Юсов, які визначають інтеграцію як універсальний підхід до вивчення мистецтва. Різноманітні аспекти інтегративних процесів у вищих мистецьких навчальних закладах знайшли відображення в наукових працях Н. Гуральник, Н. Згурської, О. Олексюк. Методологічними проблемами інтеграції опікуються С. Гончаренко, I. Козловська, Ю. Мальований. Найповніше проблема інтеграції навчальних дисциплін в галузі музично-педагогічної освіти розглядається в працях Ж. Карташової, де аналізуються інтеграційні зв'язки між інструментальновиконавськими дисциплінами в процесі фахової підготовки майбутніх учителів музики [4].

Проте аналіз наукових праць засвідчив, що сучасними дослідженнями недостатньо висвітлені розробки, конструкції яких спрямовані на продукування дієвих методик підвищення рівня підготовки учителів музичного мистецтва в процесі інтеграції дисциплін музичнопедагогічного циклу, що й зумовило вибір теми статті.

Мета статті - визначення й теоретичне осмислення інтегративних процесів у професійній підготовці майбутніх учителів музики початкової школи.

Виклад основного матеріалу. Професійна діяльність учителів музики неможлива поза творчою природою мистецтва та педагогічною діяльністю, оскільки в основі освітнього процесу постійний творчий пошук педагога. Діапазон педагогічної творчості надзвичайно широкий. Він може мати свій прояв і в підході до учня, і в здатності педагога максимально організовано, педагогічно обгрунтовано застосовувати в освітньо-виховному процесі різноманітні форми й методи навчання та виховного впливу; у здатності вирішувати різні педагогічні завдання в постійно мінливих умовах. Музичне мистецтво за своєю творчою природою надає безліч можливостей для прояву творчого потенціалу майбутніх учителів музики в початковій школі. Це стосується виконавства, інтерпретації музичних творів, педагогічної імпровізації тощо. Їм необхідно виявити себе як високоосвічених педагогів й музикантів. За роки навчання майбутні фахівці повинні оволодіти грою на музичному інструменті, 


\section{ІНТЕГРАЦІЯ МУЗИЧНО-ПЕДАГОГІЧНИХ КОМПОНЕНТІВ У ПРОФЕСІЙНІЙПІДГОТОВЦ МАЙБУТНІХ УЧИТЕЛІВ МУЗИКИ В ПОЧАТКОВІЙ ШКОЛІ}

технікою хорового диригування, вокальними навичками, методикою музичного виховання, розширити свій музичний світогляд, знати ключові постулати педагогіки. На основі всього цього в особистості повинна сформуватися культура слухацького сприйняття й музичного мислення, усвідомлення того, що представляє собою естетична сутність музики.

Загально-професійний блок дисциплін представляє собою відносно автономні, але взаємообумовлені системи підготовки: психологопедагогічну (загальна педагогіка й психологія), спеціально-наукову (історія музичного мистецтва, теорія музики, методика викладання музики). Інтеграція дисциплін музично-виконавського циклу в підготовці майбутніх учителів музичного мистецтва закладає основи їхнього професіоналізму за рахунок синтезу фахово-інструментальних та психолого-педагогічних знань, їх особистісного осмислення, а також розвитку умінь проектувати результат музично-педагогічної діяльності та здійснювати іiі рефлексивну корекцію на основі емоційного осягнення художнього змісту музичних творів [2, 86].

Курс музичних дисциплін один із компонентів професійної підготовки вчителів музики. Спеціалізована підготовка вчителя музики спрямована на оволодіння сукупністю спеціальних знань $з$ предметів інструментального, диригентськохорового циклів. Окрім цього, спеціалізація передбачає знання різних специфічних методик, педагогіки й психології музичної освіти. Таким чином, цілісна професійна підготовка вчителів музики тісно взаємопов'язана та взаємозумовлена педагогічними та музичними компонентами. У процесі формування усвідомлених знань та умінь інтеграція відіграє винятково важливу роль. Різнобічний підхід до явищ та об’єктів, можливість розглянути їх під різними кутами зору сприяють глибшому розумінню та засвоєнню знань, умінь та навичок. Особливо важливим це $\epsilon$ у фаховій підготовці, коли на порядку денному стоїть питання про формування в майбутніх учителів цілісної системи знань та умінь, яка за своєю суттю $\epsilon$ динамічним утворенням. Воно змінюється під впливом зовнішніх чинників, відбувається переструктуризація знань та їх оптимізація. Тому однією з важливих вимог до змісту навчального матеріалу є оптимально доступна та економна логіка формування музично-виконавських знань, умінь та навичок, розкриття основних галузей практичного застосування теоретичного знання, необхідність реалізації міжпредметних зв'язків [3,81].

Аналіз психолого-педагогічної літератури дає можливість стверджувати, що інтеграція в освітньому просторі може виступати:

- принципом, що проявляється в трансформації всіх складових освітніх систем (інтеграційні освітні програми, навчальні курси, уроки, створені за цим принципом школи тощо);

- засобом, що забезпечує цілісне сприйняття світу людиною та ііі здатністю системно міркувати при вирішенні різноманітних завдань;

- провідною тенденцією оновлення змісту освіти. Головним завданням у цьому випадку $є$ вибір об'єктів інтеграції та їі механізмів. Ними можуть виступати види знань, наукові знання, моделі об'єктивних процесів;

- як процес, характерною ознакою якого є визначення єдиного базису для об'єднання синкретичних елементів (рис. 1).

Також аналіз літератури дає підставу для виділення основних напрямків інтеграційних процесів в освіті на сучасному етапі: інтеграції освіти, науки, виробництва, ступенів професійної освіти, інтеграції змісту освіти.

Ми вважаємо найважливішою умовою, що об'єднує знання й уміння майбутніх учителів музики в єдине ціле, формування фундаментальної педагогічної спрямованості на всіх рівнях професійної освіти, здійснення комплексної послідовної підготовки його до майбутньої професійної діяльності. Переконані, що тільки на основі інтеграції формування загальнопедагогічних і спеціальних знань й умінь можна створити умови для оволодіння професійною майстерністю вчителями музики. Якщо ж переважає розвиток одного з компонентів, то це сприяє ускладненням і диспропорціям в здійсненні музично-педагогічної діяльності. Важливо зазначити, що, вступивши до закладу вищої освіти, майбутні педагоги різних спеціальностей отримують більш-менш рівноцінну підготовку з усіх предметів, у той час, як майбутні вчителі музики (у силу необхідної початкової музичної освіти) у переважній більшості приходять з уже сформованим певним запасом спеціальних знань та умінь (виконавських), які в навчальному закладі доповнюються й удосконалюються. Разом з тим психологопедагогічні знання в них найчастіше відсутні.

Таким чином, спеціальна підготовка спочатку випереджає загальний професійно-педагогічний рівень майбутніх учителів-музикантів. Усунути цю суперечність можливо лише в тому випадку, якщо в процесі їх освіти ставиться завдання комплексної професійної підготовки. Однак варто зауважити, що сукупність навчальних предметів чи їх компонентів, а також галузей знань у межах однієї дисципліни є суттю інтеграції. Тому 


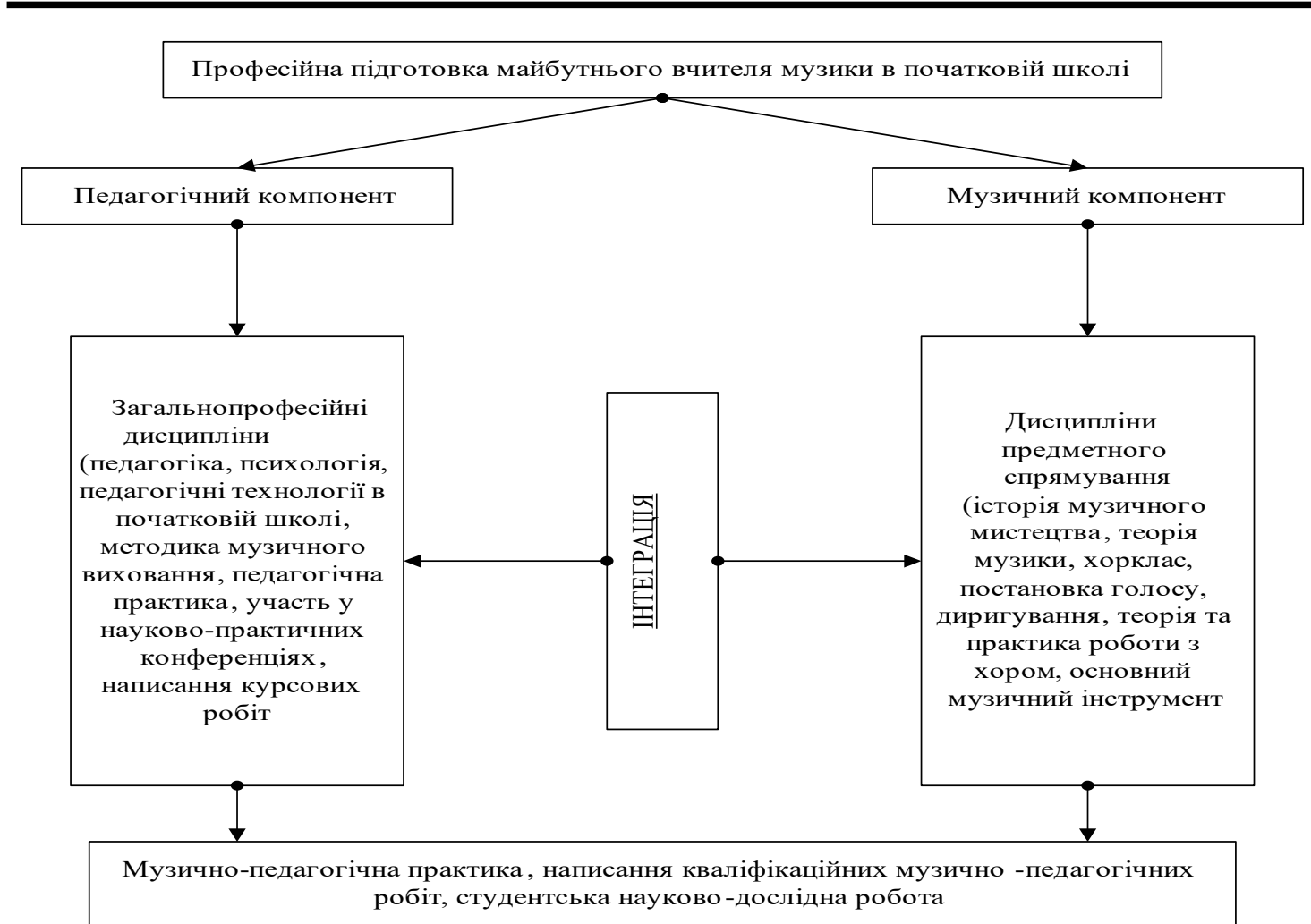

Рис. 1. Схема професійної підготовки майбутнього вчителя музики в початковій школі

підготовка вчителів музики до практичної роботи в загальноосвітній школі має характеризуватися посиленням міждисциплінарних зв'язків, інтеграцією їх змісту, унаслідок чого може створюватися новий синтезований навчальновиховний комплекс музикознавчого й музичнопедагогічного знання та більш продуктивно здійснюватися накопичення в студентів інтегрованих умінь [5, 164]. У цьому випадку необхідна базова ідея, що дозволить забезпечити й реалізувати нерозривний зв'язок і цілісність навчального курсу. Тільки за такої умови інтеграція буде спрямована на підвищення ефективності та цілісності процесу професійної підготовки майбутніх учителів музики.

Інтеграційні процеси в освіті виступають, 3 одного боку, як об'єднання організаційних структур, що пов'язані з нею, з іншого боку, як інтеграція навчальної, наукової та професійної діяльності; інтеграція спеціальностей; інтеграція змісту навчальних предметів; інтеграція змісту знань й умінь, пов'язаних 3 різними кваліфікаційними рівнями професійної підготовки.

Інтеграція розглядається нами як складноструктурований педагогічний процес, що вимагає:

- навчити студентів розглядати та аналізувати будь-які явища з різних позицій;

- уміння використовувати знання з різних галузей у вирішенні конкретизованого творчого завдання;
- формування в майбутніх учителів музики умінь креативно та самостійно проводити творчі дослідження.

Професійна підготовка майбутніх учителів у вищому закладі освіти передбачає, з одного боку, оптимізацію навчання, що має прояв у найбільш доцільно побудованому освітньому процесі, а 3 іншого активізацію, де акцент робиться на створення сприятливих умов для навчання.

Реалізація принципу інтеграції в процесі професійної підготовки, на наш погляд, буде сприяти:

- самовизначенню й самореалізації фахівця в обраних сферах професійної та суміжною з нею діяльностях;

- удосконаленню системного мислення, що дозволить оперативно усвідомлювати явища в усіх їх взаємозв'язках;

- забезпеченню цілісного розвитку особистості;

- встановленню більш тісних зв'язків навчання 3 практичною діяльністю.

Висновки. Отже, професійна підготовка вчителів музики полягає в оволодінні ними комплексом спеціальних знань 3 предметів, а саме: історико-теоретичних, виконавських, диригентсько-хорового циклів. Крім того, підготовка передбачає не тільки знання спеціальних методик, зокрема музичної освіти, а й теоретичних основ загальної, вікової педагогіки й психології. Професійна майстерність учителів 
музики забезпечується лише за умови, якщо спецпідготовка входить у синкретичну систему естетичної, загальнокультурної та психологопедагогічної підготовки. Спеціальна предметнопрофесійна підготовка - це єдиний комплекс музично-теоретичної, інструментальної, виконавської, диригентсько-хорової підготовки, що дозволяє здійснювати музично-педагогічну діяльність, завдяки якій формується професійна культура майбутніх учителів музики.

Можна стверджувати: вирішити завдання музично-естетичного виховання під силу лише висококваліфікованому, компетентному фахівцю, який поєднує різнобічну музичну майстерність 3 практичною готовністю до різних видів музичноестетичної діяльності в якості педагога, музиканта, просвітителя. Таким чином, професійна компетентність учителів музики включає, на наш погляд, дві основні складові: педагогічну й музичну.

Оскільки в професійній діяльності майбутніх учителів музики представлені музичний та педагогічний компоненти, процес навчання студентів необхідно будувати на основі їх інтеграції. Така необхідність диктує завдання комплексної професійної підготовки студентів, майбутніх учителів музики, перш за все в рамках одного музичного циклу, а потім і між ними, 3 опорою на знання та вміння, що отримані студентами під час вивчення психологопедагогічних дисциплін.

Резюмуючи вищесказане, можна зазначити, що всі автори сходяться на тому, що інтеграція в освіті розуміється як процес утворення з безлічі елементів сталої єдності, що має цілісні властивості. Розвивальна функція інтеграції виявляється в процесі формування гнучкої системи знань, способів дії, у силу чого виявляються нові резерви мислення, взаємодії логічного та образного в освітньо-виховному процесі.

\section{ЛІТЕРАТУРА}

1. Горюнова Л. В. Размышления о проблемах музыкально-педагогического факультета. Музыка в школе. 1984. № 1. С. 17-21.

2. Економова О. С. Інтеграція дисциплін музично-виконавського циклу у професійній підготовці майбутніх учителів музичного мистецтва. Музичне мистецтво в освітологічному дискурсі № 1, 2016. С. 85-88.

3. Карташова Ж. Обгрунтування методики фахової підготовки майбутнього вчителя музики у процесі інтеграції музично-виконавських дисциплін. Актуальні питання гуманітарних наук. Вип. 14, 2015. С. $79-86$.
4. Лабунець В. М. Інтегроване навчання майбутніх учителів музики: теорія та практика : монографія. Кам'янець-Подільський, 2013. 200 с.

5. Ревенчук В. В. Фортепіанна підготовка як складова професійного становлення майбутнього вчителя музики. Наукові записки НДУ ім. М. Гоголя. Серія: “Психолого-педагогічні науки”. 2017. №1. С. 163-167.

6. Шишлянникова Н. П. Интегрированный подход к профессиональной подготовке будущего учителя музыки. Вестник ТГПУ (TSPU Bulletin). 2012. № 11 (126). C. 38-41.

\section{REFERENCES}

1. Horiunova, L. V. (1984). Razmyshlenyia o problemakh muzykalno-pedahohycheskoho fakulteta [Thoughts about the problems of music-pedagogical faculty]. Music at school. Vol. 1. pp. 17-21. [in Russian].

2. Ekonomova, O. S. (2016). Intehratsiia dystsyplin muzychno-vykonavskoho tsyklu u profesiinii pidhotovtsi maibutnikh uchyteliv muzychnoho mystetstva [Integration of disciplines of music-executing cycle in professional training of future musical art teachers]. Musical art in educational discourse. Vol. 1. pp. 8588. [in Ukrainian].

3. Kartashova, Zh. (2015). Obhruntuvannia metodyky fakhovoi pidhotovky maibutnoho vchytelia muzyky u protsesi intehratsii muzychnovykonavskykh dystsyplin [Methodology validation of special training of future music teachers in the process of integration of music-executing disciplines]. Topical issues of humanitarian sciences. Vol. 14. pp.7986. [in Ukrainian].

4. Labunets, V. M. (2013). Intehrovane navchannia maibutnikh uchyteliv muzyky: teoriia ta praktyka : monohrafiia [Integrative learning of future music teachers: theory and practice: monograph]. Kamianets-Podilskyi. 200 p. [in Ukrainian].

5. Revenchuk, V. V. (2017). Fortepianna pidhotovka yak skladova profesiinoho stanovlennia maibutnoho vchytelia muzyky [Piano training as a component of professional development of future music teacher]. Scientific proceedings of National State University named after Mykola Hohol. Series: "Psychological and pedagogical sciences" Vol. 1. pp. 163-167. [in Ukrainian].

6. Shyshliannykova, N. P. (2012). Yntehryrovannyi podkhod k professyonalnoi podhotovke budushcheho uchytelia muzyky. [Integrative approach to professional training of future teacher]. Journal of Tomsk State Pedagogical University (TSPU Bulletin). Vol. 11 (126). pp. 38-41. [in Russian].

Стаття надійшла до редакції 08.01.2020 